\title{
The Effect of Design Thinking-based STEAM Education on Elementary School Student Interest in Math and Science, Personality, and Science and Technology Career Choice
}

\author{
Jinmi Tae \\ Graduate School of Education, Soongsil University, 369-Sangdo-Ro, \\ Dongjak-Gu, Seoul 06978, Korea \\ jmtae91@hanmail.net
}

\begin{abstract}
This study confirmed the effect of STEAM education programs for elementary school students developed based on Design Thinking principles on elementary school students' personalities, interest in science and mathematics, and choice to pursue a career in science or engineering. The results show that, first, there was no significant difference in improvement of interest in science and math between experimental and control groups. However, second, there was a significant improvement in the caring domain of personality, as well, third, as a significant increase in science and technology career choice. On the whole, these results imply that creative science and technology training that satisfies the needs of the networked age, which emphasizes collective intelligence, is feasible.
\end{abstract}

Keywords: Design thinking, STEAM, Creative problem-solving, Science and technology talent, Science and technology career choice

\section{Introduction}

STEAM stands for science, technology, engineering, the arts, and mathematics, and STEAM education, which is currently being promoted in Korea, is education that boosts student interest and understanding in science and technology and develops science- and technology-based "STEAM literacy" and "real-life problem-solving ability" [1][2][3]. No matter how much knowledge one has, if one's "empathetic abilities" related to keenly observing and understanding the needs of people around one, or "implementation abilities" to resolve real problems by cooperating and communicating with people from various sectors, are lacking, there will many limitations regarding the applied potential of creativity [4][5][6]. Therefore, this study was carried out in order to help address this gap by investigating the feasibility of educational content designed to foster creative science and technology talent in a way that improves communication and cooperation, by confirming the effect that convergenttype creative education content in STEAM education has on elementary school students' personalities, interest in science and technology, and choice to pursue a career in science and/or technology.

\footnotetext{
${ }^{1}$ This work was supported by a 2015 Korea Foundation for the Advancement of Science and Creativity (KOFAC) grant funded by the Korean Ministry of Education.
}

Article history:

Received (September 22, 2016), Review Result (November 13, 2016), Accepted (December 28, 2016) 


\section{Design thinking-based STEAM education design model}

The initial goal of STEAM education is to develop convergent thinking skills and creative problem-solving skills and to make possible an "emotional experience" wherein the learner experiences feelings of success rather than simply recognizing his or her acquisition of knowledge. If this emotional experience can be provided in elementary education, STEAM education at the elementary level will be enhanced and will align with subject linked-style systems, and creative design will pass beyond or transcend the Design Thinking stage shown below in [Figure 1] and spread (according to Design Thinking principles). At the situation presentation stage, the entire program is embraced through the introduction of problems to elicit student interest and motivation, presented in a fun storytelling format but also in a familiar manner that induces natural convergence. At the creative design stage, plans are made for the emphasize-define-ideate-prototype production/testing stages, a problem-solving approach that addresses hidden user needs in the product from various perspectives becomes available [Figure 1].

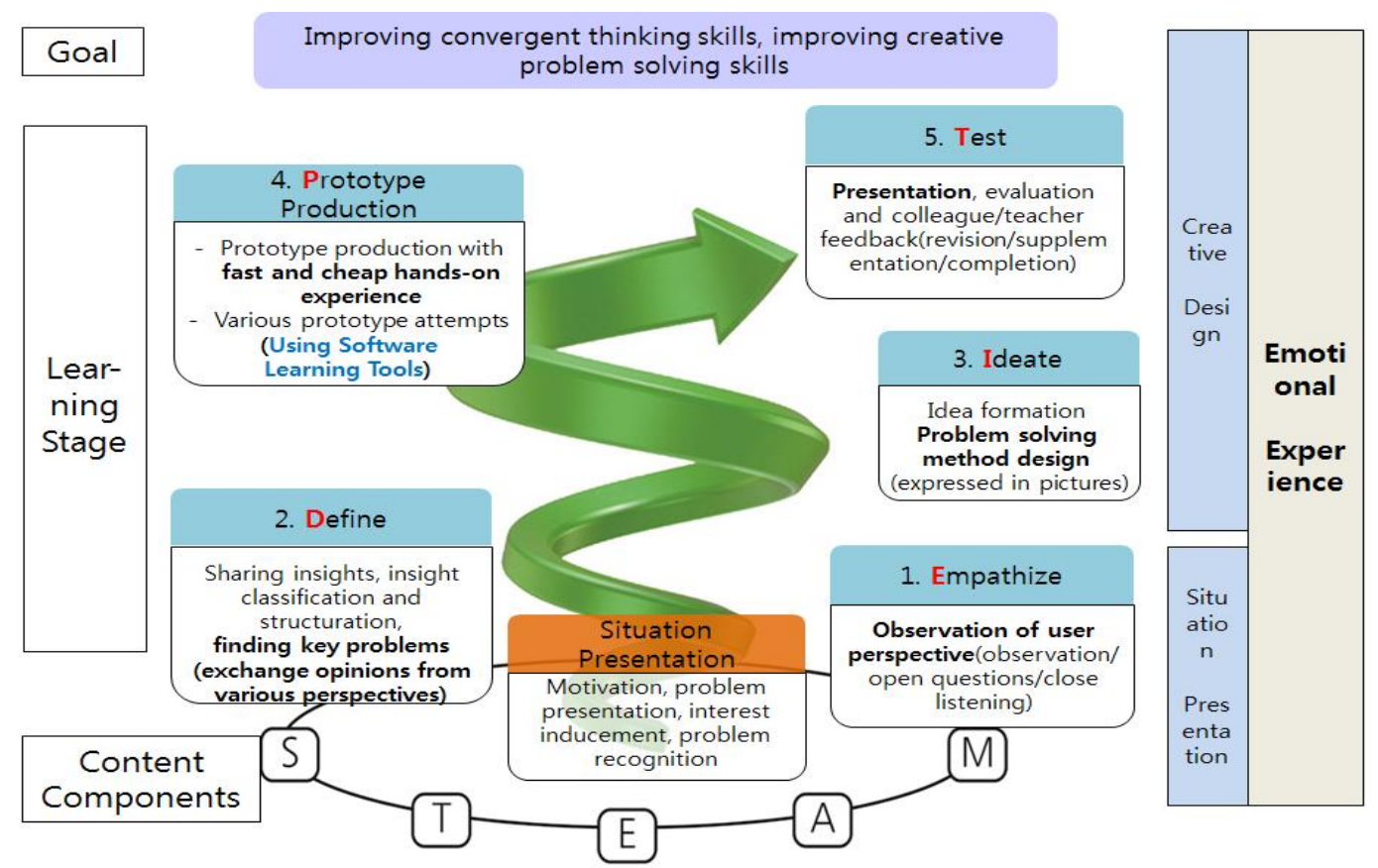

Figure 1. Design thinking-based STEAM education design model

\section{Methods}

\subsection{Study participants}

In this study, 196 students were randomly selected from grades 3, 4, 5, and 6 of elementary schools $\mathbf{J}$ and $\mathrm{H}$, located in Seoul, in order to confirm the effects of Design Thinking-based STEAM education programs on elementary students' personalities, interest in science and technology, and science and technology career choice. The two schools were similar in terms of personal and physical environments as well as educational philosophy and curriculum; the demographics of the study participants are shown in [Table 1] below. 
Table 1. Composition of student study participants

\begin{tabular}{|c|c|c|c|c|c|c|}
\hline & & \multicolumn{4}{|c|}{ Grade Year } & \multirow{2}{*}{$\mathrm{N}(\%)$} \\
\hline & & 3 & 4 & 5 & 6 & \\
\hline \multirow{2}{*}{ Control Group } & Male & $11(5.7)$ & $11(6.3)$ & $11(5.71)$ & $12(6.27)$ & $45(23.98)$ \\
\hline & Female & $11(5.7)$ & $12(6.35)$ & $11(5.71)$ & $12(6.27)$ & $46(24.03)$ \\
\hline \multirow{2}{*}{$\begin{array}{l}\text { Experimental } \\
\text { Group }\end{array}$} & Male & $13(6.55)$ & $13(6.4)$ & $13(6.54)$ & $13(6.48)$ & $52(25.97)$ \\
\hline & Female & $13(6.55)$ & $14(6.45)$ & $13(6.54)$ & $13(6.48)$ & $53(26.02)$ \\
\hline \multicolumn{2}{|c|}{ Total } & $48(24.5)$ & $50(25.5)$ & $48(24.5)$ & $50(25.5)$ & $196(100)$ \\
\hline
\end{tabular}

Before the experiment was run for the two groups of students, a pre-screening was conducted to ensure the homogeneity of each group.

\subsection{Experiment design and process}

The experiment was run over 2 months, with a total of 12 sessions of 40 minutes each for grades 3 and 4 and 16 sessions for grades 5 and 6, conducted by teachers who had received preliminary training in Design Thinking-based STEAM education principles and methods. The experimental group was taught using a Design Thinking-based STEAM education program (science, practical, Korean, math, art, music, etc.) and the control group went to their regular classes. Preliminary and post-examinations for the control and experimental groups are summed up in [Table 2] below.

Table 2. Experiment design

\begin{tabular}{|c|c|c|c|}
\hline Study Participant & Preliminary Examination & Experimental Treatment & Post Examination \\
\hline R1 & O1 & $\mathrm{X}$ & $\mathrm{O} 2$ \\
\hline R2 & $\mathrm{O} 3$ & & $\mathrm{O} 4$ \\
\hline
\end{tabular}

R1: Experimental group R2: control group

O1: Experimental group preliminary examination (math/science interest, personality, science and technology career choice)

O2: Experimental group post examination (math/science interest, personality, science and technology career choice)

O3: Control group preliminary examination (math/science interest, personality, science and technology career choice)

O4: Control group post examination (math/science interest, personality, science and technology career choice)

X: Design Thinking-based STEAM education program 12/16 sessions

\subsection{Examination tools}

This study used a tool developed by Park (2014) to examine elementary students' personalities, levels of interest in science and math, and science and technology career choices in order to verify definitive outcomes and improve the effectiveness of the STEAM education program implemented by the Korea Foundation for Creativity and Science [8]. This 
tool was found to be satisfactory, with a reliability rating of .74-.83; item-specific reliability ratings are below in [Table 3].

Table 3. Question composition and reliability of examination tool

\begin{tabular}{|c|c|c|c|}
\hline \multicolumn{2}{|c|}{ Item } & \# of Questions & Reliability \\
\hline \multirow{2}{*}{$\begin{array}{c}\text { Science/Math } \\
\text { Interest }\end{array}$} & Math & 5 & .86 \\
\cline { 2 - 4 } & Science & 5 & .84 \\
\hline \multirow{2}{*}{ Personality } & Caring & 5 & .85 \\
\cline { 2 - 4 } & Communication & 5 & .84 \\
\hline \multicolumn{2}{|c|}{ Science and Technology Career Choice } & 3 & .76 \\
\hline
\end{tabular}

\subsection{Research tools}

The Design Thinking-based STEAM education program investigated here was developed by Tae (2016). It is based on the validity of the connection between elementary curriculum and ethical, class design, functional, and evaluative considerations for professionals in related industries [7]. The program is designed to cultivate interest and creative ability in math, science, and technology and foster experience caring and communicating. Detailed class syllabi for the experimental and control groups are given in [Table 4] below.

Table 4. Class syllabi used in the experiment

\begin{tabular}{|c|c|c|c|c|}
\hline & \multicolumn{2}{|c|}{ Middle Grades $(3,4)$} & \multicolumn{2}{|c|}{ High Grades $(5,6)$} \\
\hline & Experimental Group & Control Group & Experimental Group & Control Group \\
\hline 1 & $\begin{array}{c}\text { Real smile } \\
\text { Fake smile (E,A) }\end{array}$ & $\begin{array}{l}\text { Understanding the effects } \\
\text { of nonverbal expression }\end{array}$ & \multirow{2}{*}{$\begin{array}{l}\text { Getting familiar with } \\
\text { Little Bits } \\
\text { (T, E, M) }\end{array}$} & \multirow{2}{*}{$\begin{array}{l}\text { Learning about } \\
\text { products that use } \\
\text { sensors and their } \\
\text { principles }\end{array}$} \\
\hline 2 & $\begin{array}{l}\text { Emotion and stress } \\
\text { indicators }(\mathrm{E}, \mathrm{M})\end{array}$ & $\begin{array}{l}\text { Collecting real-life data } \\
\text { and drawing graphs }\end{array}$ & & \\
\hline 3 & $\begin{array}{c}\text { Same face different } \\
\text { feeling } \\
\text { Science hidden in } \\
\text { laughter }(\mathrm{S}, \mathrm{T}, \mathrm{A}) \\
\end{array}$ & $\begin{array}{c}\text { Location and appearance } \\
\text { of bodily organs }\end{array}$ & \multirow{2}{*}{$\begin{array}{c}\text { Tracking with } \\
\text { flashlights at night for } \\
\text { play } \\
(\mathrm{S}, \mathrm{T}, \mathrm{E})\end{array}$} & \multirow{2}{*}{$\begin{array}{l}\text { Understanding } \\
\text { properties of lights } \\
\text { and making lights } \\
\text { of various colors }\end{array}$} \\
\hline 4 & $\begin{array}{c}\text { Getting familiar with } \\
\text { Little Bits small toys (S, } \\
\text { T, E) }\end{array}$ & $\begin{array}{l}\text { Principles of magnets } \\
\text { (pushing forces and } \\
\text { pulling forces) }\end{array}$ & & \\
\hline 5 & \multirow{2}{*}{$\begin{array}{c}\text { Planning/producing "a } \\
\text { fun face" with Little Bits } \\
(\mathrm{S}, \mathrm{T}, \mathrm{T}, \mathrm{A})\end{array}$} & \multirow{2}{*}{$\begin{array}{l}\text { Look at my friend's face } \\
\text { and drawing its features }\end{array}$} & \multirow{2}{*}{$\begin{array}{l}\text { Designing a fun } \\
\text { doorbell } \\
\text { (T, E, A) }\end{array}$} & \multirow{2}{*}{$\begin{array}{l}\text { Making creative } \\
\text { cars using various } \\
\text { materials }\end{array}$} \\
\hline 6 & & & & \\
\hline 7 & $\begin{array}{l}\text { Picking an insect I like } \\
\text { (A) }\end{array}$ & Lifestyles of animals & \multirow{2}{*}{$\begin{array}{l}\text { Making a car installed } \\
\text { with a sensor }(\mathrm{T}, \mathrm{E})\end{array}$} & \multirow{2}{*}{$\begin{array}{l}\text { Making creative } \\
\text { cars using various } \\
\text { materials }\end{array}$} \\
\hline 8 & $\begin{array}{l}\text { Making the sound of the } \\
\text { insect I like (T, E, A) }\end{array}$ & Insect that I like & & \\
\hline 9 & $\begin{array}{l}\text { Future insect that I } \\
\text { imagine (I) } \\
(\mathrm{S}, \mathrm{A})\end{array}$ & $\begin{array}{l}\text { Environmental changes of } \\
\text { future society }\end{array}$ & \multirow{2}{*}{$\begin{array}{c}\text { Designing } 3 \text { modules } \\
\text { utilizing play } \\
\text { activities }(\mathrm{T}, \mathrm{E}, \mathrm{A})\end{array}$} & \multirow{2}{*}{$\begin{array}{l}\text { Designing creative } \\
\text { household items } \\
\text { using various } \\
\text { materials }\end{array}$} \\
\hline 10 & $\begin{array}{c}\text { Expression through Little } \\
\text { Bits } \\
(\mathrm{T}, \mathrm{E}, \mathrm{A}, \mathrm{M}) \\
\end{array}$ & $\begin{array}{l}\text { Try making a variety of } \\
\text { different sounds }\end{array}$ & & \\
\hline 11 & Future insect that I & Try to make various & Principle and design & Learning the \\
\hline
\end{tabular}




\begin{tabular}{|c|c|c|c|c|}
\hline 12 & imagine II & $\begin{array}{c}\text { sounds with an instrument } \\
\text { we made } \\
\text { Creating sounds with } \\
\text { Little Bits(S, T, E, A) }\end{array}$ & of rides (S, A, M) & principles of rides \\
\hline & & & $\begin{array}{c}\text { Design and } \\
\text { production of user-led } \\
\text { customized rides } \\
\text { (S, T, E, A, M) }\end{array}$ & $\begin{array}{c}\text { Designing and } \\
\text { producing rides }\end{array}$ \\
\hline & & $\begin{array}{c}\text { Exhibition for our } \\
\text { class's ride(A) }\end{array}$ & $\begin{array}{c}\text { Exhibition for our } \\
\text { class's ride }\end{array}$ \\
\hline
\end{tabular}

\subsection{Data processing}

A preliminary examination was conducted on student participants who were separated into an experimental group and a control group to confirm group homogeneity, as described above, after which they went through 12 or 16 class sessions for the experimental treatment, which was followed by a post-examination. Collected data were analyzed with SPSS 22.0 for Windows, and an independent-groups t-test was done on the results of the two groups' preliminary and post-examinations in order to discern the effect that Design Thinking-based STEAM education had on elementary student personality, interest in math and science, and science and technology career choice.

\section{Results}

\subsection{Effect on interest in math and science}

There was no significant difference in improvement of interest in science and math between experimental and control groups.

\subsection{Effect on personality}

The results of the personality factors, the 'caring' average was higher in the experimental group ( $\mathrm{M}=3.124)$ than in the control group $(\mathrm{M}=2.890)$, and at a $\mathrm{p}<.01$ standard, there was a significant improvement, but in the 'communication' area, there was no significant difference or change, nor were there by gender or grade year.

\subsection{Effect on science and technology career selection}

The results of this investigation into the effects of Design Thinking-based STEAM education programs on elementary school student science and technology career choice are given below. The average score of the experimental group $(M=3.074)$ was higher than that of the control group $(\mathrm{M}=2.915)$ and was statistically significant at $\mathrm{p}<.05$. The average score for male students $(M=3.074)$ was statistically higher than that for females $(M=2.761)$ at $p<.05$, but there was no significant difference in the experimental group by gender. Following the experimental treatment, an analysis into the difference in participants' science and technology career choices between groups by grade year found no statistically significant difference between the experimental group and the control group. 


\section{Conclusion}

The results of this study can be interpreted as follows. First, the investigation into the effect of Design Thinking-based STEAM education on elementary school students' interest in math and science found no significant effect, contrary to the benefit claimed for STEAM education by the Korean government: that it improves student interest in science and technology. Second, the finding of a significant improvement in the personality factor of 'caring' is likely related to with principles emphasized by Design Thinking and human-led designs rather than regular creative designs. Third, the finding of a meaningful increase in elementary students' science and technology career choice in the experimental group but not the control group showed that the STEAM activities satisfied their fundamental goal. However, we should be careful about the generalization of this study's results, since it included just 196 participants from metropolitan elementary, and also since the scale used to verify effectiveness was based on learners' individual, subjective judgments. In the future, effectiveness should be verified in multiple, objective ways, and students' initial characteristics and changes in them investigated in more detail.

\section{References}

[1] Y. S. Baek, H. J. Park, Y. M. Kim, S. G. Noh, J. Y. Lee, J. S. Jeong, Y. H. Choi, and H. S. Han. "Steam education in Korea," Journal of Learner-Centered Curriculum and Instruction, vol.11, no.4, (2011)

[2] V. P. Glăveanu, "Principles for a cultural psychology of creativity," Culture \& Psychology, vol.16, no.2, (2010)

[3] R. J. Sternberg and T. I. Lubart, "An investment theory of creativity and its development," Human Development, vol.34, no.1, (1991)

[4] KOFAC, "Ministry of education of the republic of Korea," STEAM Handbook, KOFAC, Seoul, (2012)

[5] J. S. Kim, Editor, STEAM Education, Yangseowon, Seoul, (2012)

[6] T. Kelley and D. Kelly, Editor, "Creative confidence: unleashing the creative potential within us all," Penguin Random House Company, New York, (2013)

[7] J. M. Tae, Editor, "Development of STEAM education content utilizing the most advanced product by KOFAC," KOFAC, Seoul, (2016)

[8] H. J. Park, Editor, "Research Report on Effectiveness of STEAM program in Korea," KOFAC, Seoul, (2014)

\section{Authors}

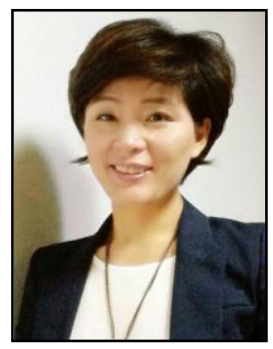

Jinmi, Tae

Professor, Soongsil University

Research Director, Development of STEAM Education Content Utilizing the Most Advanced Product by $\operatorname{KOFAC}(2015,2016)$ 